\title{
Impact of Nitrogen Fertilization on Soil Organic Carbon Decomposition
}

\author{
Mostafa Y. Khalafalla ${ }^{1}$ and Mahdy H. Hamed ${ }^{2}$
}

\begin{abstract}
A field study was conducted at The Experimental Farm, Fac. of Agric., Al-Azahar University, Assuit, located $375 \mathrm{~km}$ south of Cairo, Egypt $\left(27^{\circ} \quad 12-16.67=\mathrm{N}\right.$ latitude and $31^{\circ}$ 09- 36.86 $=\mathrm{E}$ longitude) through wheat growing season 2015. The aim of current study is to asses the effect of nitrogen fertilizer types (urea and ureaform) at different levels on soil organic carbon decomposition.

Soil organic carbon decomposition percentage (SOCD) is at a minimum amount in the $2^{\text {nd }}$ week and at a maximum amount in the $7^{\text {th }}$ week at the recommended urea level $-15 \%(\mathrm{R}-15 \%)$. The biweekly SOCD \% varied from 0.82 and $9.55 \%$ at $70 \mathrm{~kg} \mathrm{~N} /$ fed level (R-30\%). SOCD\% ranged between 0.16- 12.73, 5.14- 10.61 and 0.41$8.78 \%$ for ureaform level at (R-15\%) and (R-30\%) less than the recommended one $(R)$, respectively. The amount of soil $\mathrm{CO}_{2}$ flux from recommended ureaform level treatment was the highest one during the entire growing season. Overall, SOCD\% followed the order of R $>$ R-15\% $>\mathrm{R}-30 \%$. The highest values of SOCD \% were 8.4 and 8.2 at $2.4 Q_{10}$ value with urea and at $2.7 Q_{10}$ value with ureaform, respectively. The lowest values of SOCD \% were 2.3 and 4.4 at $2.2 Q_{10}$ value with urea or ureaform, respectively. Soil $\mathrm{C}: \mathrm{N}$ raties under all treatments were higher than that of initial state except that under R-30\% of urea. The soil $C: N$ ratio was higher at $R-15 \%$ of urea than that when soil treated by ureaform. The opposite trend is true at $\mathbf{R - 3 0} \%$.
\end{abstract}

Key words: Nitrogen fertilizer, Soil carbon decomposition, $\mathrm{C}: \mathrm{N}$ ratio, Temperature sensitivity, Wheat crop.

\section{INTRODUCTION}

Nitrogen $(\mathrm{N})$ is a substantial element for all life on Earth. Litter decomposition is essential for the cycling of carbon (C) and nutrients in terrestrial ecosystems. By decomposition, $\mathrm{C}$ and nutrients that immobilize in the litter are released and once again becomes available to plants. Overall, it is controlled by the interactions between the decomposer organisms, the litter properties, and the abiotic environment. However, the interactions are not yet fully understood. One interaction we do not fully understand is the one between $\mathrm{C}$ and nitrogen (Russell et al., 2006). Generally, the data indicated the increases in T-N, Av-P and Av-K as indicators of improvement in the fertility in the treated soil. The high increase in nutrients content in the soil treated with T4 $(40 \%$ M.F $+60 \%$ O.M) at the end of study may be attributed to its decomposition and producing organic acids (Abedel-Sattar et al 2011). Besides its scientific interest, understanding how $\mathrm{N}$ affects organic matter (OM) decomposition has become important in a global change perspective. During the last century, the $\mathrm{N}$ deposition has increased, mainly as a result of increased production, use of fertilizers, increased combustion of fossil fuels, and it is predicted to continue to increase (Galloway et al., 2004 \& 2008).

Nitrogen fertilization studies showed that adding $\mathrm{N}$ can increase, decrease, or have no effect on the decomposition rate (OM). A decreased or unchanged decomposition rate, together with an increased plant biomass production, may decrease the concentration of atmospheric $\mathrm{CO}_{2}$. However, if both the plant biomass production and the decomposition rate increase, the consequence for the atmospheric $\mathrm{CO}_{2}$ concentration is unclear. Given the importance of litter decomposition for element cycling in ecosystems, and the uncertainties regarding responses and feedbacks to global change, an increased understanding of the interaction between $\mathrm{C}$ and $\mathrm{N}$ during decomposition is desirable (Hobbie, 2005 and Knorr et al., 2005). It can be concluded that combined use of organic manure such as farm yard manure (FYM) with mineral nitrogen fertilizer would maintain high microbial biomass and respiration in calcareous soil (Elsokkary etal.2011).

Carbon decomposition from organic residues is controlled by many factors soil environmental conditions (temperature, moisture, aeration, soil $\mathrm{pH}$, nutrient availability, etc), substrate quality (chemical composition) and quantity, soil residue pretreatment, application methods and their potential interactions. There was a significant higher effect of inorganic $\mathrm{N}$ fertilizer on organic matter content in combination with manure than that when it applied alone. Lacking, however, is an integrated assessment of the effects of $\mathrm{N}$ fertilization on the processes that influence the soil $\mathrm{C}$ balance. The balance of organic carbon (OC) in the soil is determined by rates of (OC) inputs from net primary production (NPP) of the crops plus any manure additions, and rates of (OC) decay (Russell et al. 2006; Khan et al. 2007 and Liu et al., 2010).

The input and decay rates of (OC) can be influenced by environmental factors, including temperature, precipitation, and soil type, and by management factors such as tillage and fertilization. Fertilizer additions

\footnotetext{
${ }^{1}$ Soils \& water Dept., Fac. Agric., Al-Azhar Univ., Assuit, Egypt.

${ }^{2}$ Soils \& water Dept., Fac. Agric., Assuit Univ., New Valley, Egypt.

Received November 18, 2015, Accepted December 20, 2015
} 
could influence NPP, thus the quantity of (OC) inputs. Fertilization could alter the partitioning of NPP among plant components above and below ground, and thereby influence the (OC) decay rates if decay rates differ with respect to location of decomposition. Finally, N fertilization could alter the crop-tissue chemistry, which would influence its decomposition rate. Long-term studies indicated that initial $\mathrm{N}$ concentration drives litter decay rates (Johnson et al.، 2005 and Parton et al., 2007). The world's soils are estimated to contain 3000 Gt carbon, which is three times the estimated amount of atmospheric $\mathrm{CO}_{2}-\mathrm{C}$. Thus, even small changes in the soil carbon pool may severely affect the atmospheric $\mathrm{CO}_{2}$-concentration, thereby further affecting the global air temperature. The decomposition of organic material has been shown to be more sensitive to temperature than net primary production (Tarnocai et al., 2009 and Conant et al., 2011).

Decomposition is the process by which organic matter in (or on top of) the soil is converted into progressively smaller pieces and eventually inorganic compounds. Bacterial and fungal decomposers are responsible for more than $95 \%$ of the biotic part of OM decomposition. Decomposers use organic matter as a source of metabolic (e.g. carbohydrate) energy and as a source of nutrients. The form of $\mathrm{N}$ added varies across studies, yet we know little about how different $\mathrm{N}$ forms may impact microbial processes. $\mathrm{N}$ additions to soil can affect microbial activity, yet it is not clear if these impacts are a direct function of the increase in $\mathrm{N}$ availability or a result of indirect effects of the fertilizer inputs on other soil chemical characteristics. The soil C: $\mathrm{N}$ ratio is a soil fertility indicator due to the close relationship between soil organic carbon (SOC) and total nitrogen $(\mathrm{TN})$. The soil $\mathrm{C}: \mathrm{N}$ ratio is often influenced by many factors such as climate soil conditions, vegetation types and agricultural management practices. Soil organic C: $\mathrm{N}$ of 20 is generally considered to be a threshold point where either net $\mathrm{N}$ mineralization or net $\mathrm{N}$ immobilization occurs ((Bowden et al., 2004; Craine et al., 2007 and Alcantara et al., 2013).

\section{MATERIALS AND METHODS}

Field experiment was conducted at The Experimental Farm, Fac. of Agric., Al-Azahar Univ., Assuit, located $375 \mathrm{~km}$ south Cairo, Egypt $\left(27^{\circ} 12^{-} 16.67^{=} \mathrm{N}\right.$ latitude and $31^{\circ} 09^{-} 36.86^{=} \mathrm{E}$ longitude). The site is characterized by a flat topography and is dominated by well drained Entisols (Soil Survey Staff, 1996) and has clay loam in texture, is slightly alkaline and has low organic matter content but adequate potassium level in the top layers of $50 \mathrm{~cm}$ soil depth (Table 1a \& b).

The experiment was laid out in split plots design with three replicates and 6 treatments. The study included two nitrogen fertilizer sources and three levels of nitrogen. The main plots were assigned for nitrogen sources (Urea $46.5 \% \mathrm{~N}$ as a fast nitrogen fertilizer and ureaform $40 \% \mathrm{~N}$ as a slow nitrogen fertilizer). The split plots were assigned for nitrogen fertilizer levels as follows: a) at the recommended level (R), b) $15 \%$ less than the recommended level (R-15\%) and c) $30 \%$ less than the recommended level (R-30\%). In addition, there is another treatment without nitrogen fertilizer in order to asses the changes in ecosystem in uncultivated soil that could be used as controls for carbon dioxide absorbed from the atmosphere during the season. Soil moisture was adjusted to $65 \%$ of field capacity (FC). The plot area is almost $96 \mathrm{~m} 2(12 \times 8 \mathrm{~m} 2)$. The previous crop was sunflower.

In the winter season of 2014/15, wheat seeds (Triticum aestivum vulgar. CV Sids 1) were sown on December 7 th, consuming $60 \mathrm{~kg}$ seed /fed. Phosphorus fertilizer (superphosphate, $15.5 \% \mathrm{P}_{2} \mathrm{O}_{5}$ ) was broadcasted during soil preparation processes at a rate of $100 \mathrm{~kg} / \mathrm{fed}$.

Table 1. Some chemical and physical properties of the soil of the experimental site a- Physical properties

\begin{tabular}{|c|c|c|c|c|c|c|c|c|c|c|c|c|c|c|}
\hline \multirow{2}{*}{\multicolumn{2}{|c|}{$\begin{array}{l}\text { Soil } \\
\text { depth(cm) }\end{array}$}} & \multicolumn{6}{|c|}{ Particels size percentage } & \multirow{2}{*}{$\begin{array}{c}\text { Texture } \\
\text { class }\end{array}$} & \multicolumn{4}{|c|}{ Moisture content $(0 \mathrm{v} \%)$} & \multirow{2}{*}{\multicolumn{2}{|c|}{ A.W. (\%) }} \\
\hline & & \multicolumn{2}{|c|}{ Sand } & \multicolumn{2}{|l|}{ Silt } & Clay & & & \multicolumn{2}{|r|}{ F.C. } & \multicolumn{2}{|r|}{ W.P. } & & \\
\hline \multicolumn{2}{|l|}{$0-25$} & \multicolumn{2}{|c|}{26.50} & \multicolumn{2}{|l|}{40.00} & 33.50 & \multicolumn{2}{|c|}{ Clay Loam } & \multicolumn{2}{|r|}{41.00} & \multicolumn{2}{|r|}{20.30} & \multicolumn{2}{|c|}{20.70} \\
\hline \multicolumn{2}{|l|}{$25-50$} & \multicolumn{2}{|c|}{25.11} & 39.14 & \multicolumn{2}{|r|}{35.75} & \multicolumn{2}{|c|}{ Clay Loam } & \multicolumn{2}{|r|}{40.80} & \multicolumn{2}{|r|}{20.00} & \multicolumn{2}{|c|}{20.80} \\
\hline \multicolumn{4}{|c|}{$\begin{array}{l}\text { F.C. = field capacity } \\
\text { a- Chemical properties }\end{array}$} & \multicolumn{3}{|c|}{ W.P. $=$ wilting point } & \multicolumn{6}{|c|}{ A.W. = available water } & & \\
\hline \multirow{2}{*}{$\begin{array}{c}\text { Soil } \\
\text { depth } \\
\text { (cm) }\end{array}$} & \multirow[t]{2}{*}{$\begin{array}{l}\text { OM } \\
(\%)\end{array}$} & \multirow[t]{2}{*}{$\begin{array}{c}\mathrm{CaCO}_{3} \\
(\%)\end{array}$} & \multirow[t]{2}{*}{$\begin{array}{l}\mathrm{pH} \\
(1: 2.5)\end{array}$} & \multirow[t]{2}{*}{$\begin{array}{c}\mathbf{E C}_{\mathrm{e}} \\
(\mathrm{dS} / \mathrm{m})\end{array}$} & \multicolumn{7}{|c|}{ soluble ions $(\mathrm{meq} / \mathrm{L})$} & \multicolumn{3}{|c|}{$\begin{array}{l}\text { Available nutrients } \\
\text { (ppm) }\end{array}$} \\
\hline & & & & & $\begin{array}{l}\mathrm{CO}_{3}+ \\
\mathrm{HCO}_{3}\end{array}$ & $\mathbf{C T}$ & $\mathrm{SO}_{4}$ & $\mathbf{C a}$ & Mg & $\mathbf{N a}$ & $\mathbf{K}$ & $\mathbf{N}$ & $\mathbf{P}$ & $\mathbf{K}$ \\
\hline $0-25$ & 2.43 & 3.41 & 7.66 & 0.95 & 2.25 & 1.20 & 6.00 & 2.50 & 1.30 & 5.24 & 0.13 & 70.00 & 9.63 & 367.00 \\
\hline $25-50$ & 2.13 & 3.11 & 7.75 & 1.10 & 2.04 & 1.10 & 5.60 & 2.40 & 1.08 & 5.07 & 0.20 & 56.50 & 9.55 & 343.00 \\
\hline
\end{tabular}


Potassium fertilizer (potassium sulphate, $48 \% \mathrm{~K}_{2} \mathrm{O}$ ) was added at a rate of $50 \mathrm{~kg} / \mathrm{fed}$ and it was divided in two equal doses added at the time of nitrogen fertilizer application. Ureaform (slow release nitrogen fertilizer) was added to the soil before sowing at different levels $(100 \mathrm{~kg}$, and $85 \mathrm{~kg}, 70 \mathrm{~kg} \mathrm{~N} / \mathrm{fed})$. While urea $(86 \mathrm{~kg}$, $73 \mathrm{~kg}$ and $60 \mathrm{~kg} \mathrm{~N} / \mathrm{fed}$ ) was divided in two equal doses added to soil before the 2 nd and 3rd irrigation. The plants were harvested 150 days after planting.

Classical chamber method was used for $\mathrm{CO}_{2}$ emission measurement by trapping in alkali solution, which allows $\mathrm{CO}_{2}$ fluxes to be measured directly from the soil (Davidson et al., 2002). The measurement chambers $(40 \mathrm{~cm} \times 23 \mathrm{~cm} \times 20 \mathrm{~cm}$, length $\mathrm{x}$ width $\mathrm{x}$ height) covered a soil surface of $0.0874 \mathrm{~m} 2$ and had transparent PVC walls. To prevent $\mathrm{CO}_{2}$ leakage to atmosphere, the chamber was inserted $3 \mathrm{~cm}$ into the soil. Soil surface $\mathrm{CO}_{2}$ flux (Fs) measurements were taken in the daytime between 09:00 and 11:00 hours biweekly using a glass jar filled with $100 \mathrm{ml}$ of sodium hydroxide $(1 \mathrm{~N})$. The jars were removed from the chambers, quickly capped, and sent to laboratory for carbon analysis according to Stevenson (1986). Carbon evolved as $\mathrm{CO}_{2}$ was estimated by the following formula (Stotzky, 1965): $\mathrm{mg} \mathrm{C}$ as $\mathrm{CO}_{2}=(\mathrm{B}-\mathrm{V}) \times \mathrm{N} \times \mathrm{E}$ where:

$\mathrm{B}=$ standard acid for the blank ( $\mathrm{ml})$

$\mathrm{V}=$ standard acid for fertilizer treatments $(\mathrm{ml})$

$\mathrm{N}=$ normality of standard acid;

$\mathrm{E}=$ equivalent weight of $\mathrm{C}$

Soil organic $\mathrm{C}$ evolved as $\mathrm{CO}_{2}$ from soil treated by fertilizer was determined by subtracting the quantity of $\mathrm{CO}_{2}-\mathrm{C}$ evolved from control from that evolved from soil fertilizer treatments. Decomposition percentage was estimated by calculating the percentage of the soil organic matter $\mathrm{C}$ evolved as $\mathrm{CO}_{2}$ after correction for the $\mathrm{CO}_{2}$ evolved from untreated soil according to Ajwa and Tabatabai (1994) using the following equation:

$\mathrm{C}$ decomposition \% $=[(\mathrm{X}-\mathrm{Y}) / \mathrm{Z})] \times 100$

Where:

$\mathrm{X}=\mathrm{C}$ evolved as $\mathrm{CO}_{2}$ from soil-fertilizer treatments (mg)

$\mathrm{Y}=\mathrm{C}$ evolved as $\mathrm{CO}_{2}$ from untreated soil (control); (mg)

$\mathrm{Z}=\mathrm{C}$ in the soil organic matter (mg)

Soil temperature (Ts) at $5 \mathrm{~cm}$ depth and volumetric soil moisture (Ms) measurements were made concurrently with soil surface $\mathrm{CO}_{2}$ flux (Fs). A soil sample was collected at the surface horizon $(0-15 \mathrm{~cm})$ to determine the gravimetric soil water content by oven drying at $105^{\circ} \mathrm{C} / 24 \mathrm{~h}$. Soil surface $\mathrm{CO}_{2}$ flux is commonly assumed to be exponentially dependant on Ts (Luo and Zhou, 2006), and this temperature is frequently modeled according to $\mathrm{Xu}$ and $\mathrm{Qi},(2001)$ using the following equation:

$$
\mathrm{Q}_{10}(\mathrm{~T})=1.05-0.02 \mathrm{~T}+0.045 \mathrm{~W}
$$

Where:

$\mathrm{Q}_{10}$ (dimensionless) is the factorial increase in Fs for every $10^{\circ} \mathrm{C}$ rise in Ts

$\mathrm{T}$ is a reference soil temperature $\left({ }^{\circ} \mathrm{C}\right)$ at soil surface

$\mathrm{W}$ is volumetric soil moisture content $(0-15 \mathrm{~cm}$ soil depth).

All measurements have been made during a short period of time in the same ecosystem suggesting that there is no significant influence from phonological differences or different compositions of the respiring pools.

\section{RESULTS AND DISCUSSION}

\section{1- Effect of urea fertilizer on soil organic carbon} decomposition.

Data presented in Fig. (1) Show the impact of urea fertilizer levels on soil organic carbon decomposition through wheat growing season. It is observed that soil organic carbon decomposition percentage (SOCD) is at a minimum amount in the 1 st week and at a maximum amount in the $7^{\text {th }}$ week at the recommended level - $15 \%$ treatment. The biweekly SOCD \% recorded at $85 \mathrm{~kg} \mathrm{~N}$ level ranged from 2.37 and $12.24 \%$, while it varied from 0.82 and $9.55 \%$ at $70 \mathrm{~kg} \mathrm{~N} /$ fed level (R-30\%). The trend line was less inclined at $70 \mathrm{~kg} \mathrm{~N}$ level than that at $85 \mathrm{~kg}$ level. The level of $70 \mathrm{~kg} \mathrm{~N} / \mathrm{fed} \mathrm{had} \mathrm{higher} \mathrm{SOCD}$ $\%$ than that at $100 \mathrm{~kg} \mathrm{~N} / \mathrm{fed}$ in the beginning of the evaluation period (till $5^{\text {th }}$ biweek) but a lower SOCD \% at the end.

The addition of urea fertilizer significantly stimulated soil organic carbon decomposition. At the completion of the study, soil organic carbon decomposition as affected by urea fertilizer ranged from 46.16 to $54.90 \%$ at 70 and $100 \mathrm{~kg} \mathrm{~N} / \mathrm{fed}$, respectively. The results indicated that the SOCD $\%$ at $70 \mathrm{~kg} \mathrm{~N} / \mathrm{fed}$ treatment was less than that at $85 \mathrm{~kg} \mathrm{~N} /$ fed or $100 \mathrm{~kg}$ $\mathrm{N} /$ fed. Overall, SOCD $\%$ followed the order of recommended level $>15 \%$ less than recommended level $>30 \%$ less than recommended level treatment.

Despite the indirect evidence for $\mathrm{N}$ limitation of decomposition, results of direct tests, in which $\mathrm{N}$ supply is experimentally increased through fertilization, are inconsistent. 


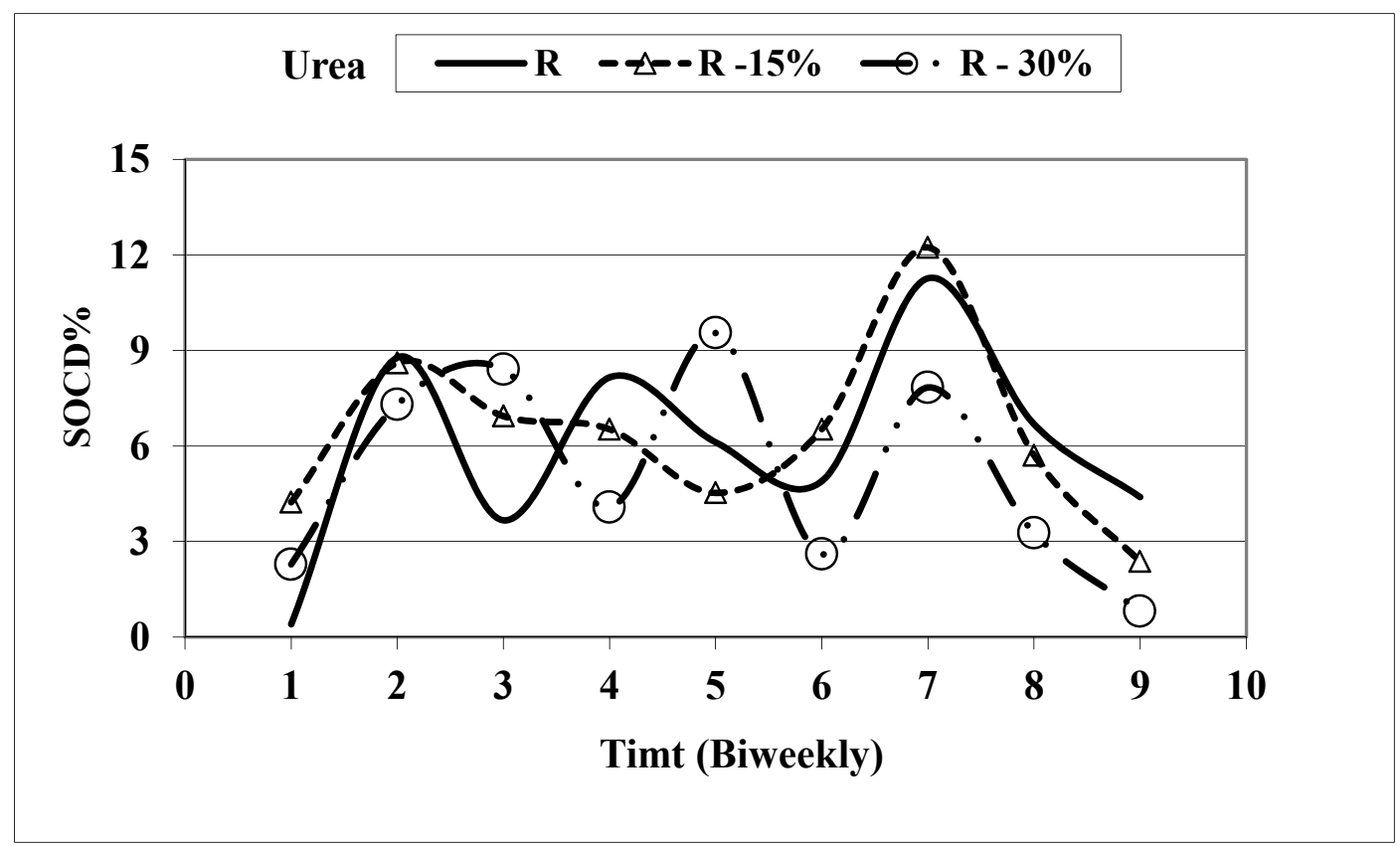

\section{Fig. 1. Soil organic carbon decomposition (SOCD) \% in relation to time when soil was fertilized by urea at different levels}

A recent meta-analysis of $\mathrm{N}$ fertilization effects on decomposition found that $\mathrm{N}$ can have stimulatory, neutral, or negative effects on decomposition depending on substrate chemistry, ambient $\mathrm{N}$ deposition rates, and the amount of $\mathrm{N}$ fertilizer added (Knorr et al. 2005). Specifically, N generally reduced decomposition of substrates with high lignin concentrations but stimulated decomposition of substrates with low lignin concentrations. These results are consistent with those of other studies showing that substrate and/or exogenous $\mathrm{N}$ may reduce lignin decomposition either by inhibiting synthesis of ligninolytic enzymes (Sinsabaugh et al. 2002) or by reacting with breakdown products of lignin degradation to form other recalcitrant compounds (Dijkstra et al. 2004).

The effects of $\mathrm{N}$ on decomposition may vary, increasing early stages of decomposition (when litter contains relatively high concentrations of labile $\mathrm{C}$ and low concentrations of $\mathrm{N}$ ) but reducing decomposition in its later stages, when the concentrations of lignin in litter have increased. Generally, increases in nitrogen concentration result in faster initial mass losses of organic C, while proportions of more recalcitrant Ccompounds increase (Berg, 2000). Kaboneka, S. et al (2004) found that the response of straw C decomposition to $\mathrm{N}$ fertilizer addition followed the order: Straw $+120 \mathrm{~kg} \mathrm{~N} \mathrm{ha}^{-1}=$ Straw $+80 \mathrm{~kg} \mathrm{~N} \mathrm{ha}^{-1}>$ Straw $+40 \mathrm{~kg} \mathrm{~N} \mathrm{ha}^{-1}>$ Straw alone.

\section{2- Effect of ureaform fertilizer on soil organic carbon decomposition.}

Soil organic carbon decomposition increased as the time proceeded and almost takes the same trend of that at Urea fertilizer (Fig. 2). Soil organic carbon decomposition percent ranged between 0.16- 12.73, 5.14- 10.61 and $0.41-8.78 \%$ for recommended level, $15 \%$ less and $30 \%$ less than recommended level treatment respectively. It is observed that the amount of soil organic carbon decomposition at treatment of $30 \%$ less than recommended level laid down that of $15 \%$ less than recommended level treatment along the growing season. The amount of soil $\mathrm{CO}_{2}$ flux from recommended level treatment was the highest during the entire growing season.

SOCD $\%$ as affected by ureaform fertilizer ranged from 37.76 with $30 \%$ less than recommended level, 65.53 with $15 \%$ less than recommended level to $67.22 \%$ with recommended level. No significant differences were observed between treatments fertilized with $15 \%$ less than recommended level and recommended level. Overall, soil organic carbon decomposition \% followed the order: recommended level $>15 \%$ less than recommended level $>30 \%$ less than recommended level.

Increases in nitrogen deposition have been shown to affect soil carbon storage positively, because they reduce saprotrophic respiration via mechanisms that shift the composition of the OM towards more chemically stable compounds. 
High $\mathrm{N}$ content also appears to suppress activities of ligninolytic fungi and their enzymes (Janssens et al., 2010; Liu \& Greaver, 2010). However, N has complex effects in decomposition processes as high $\mathrm{N}$ concentrations appear to enhance degradation in early stages of fresh litter decomposition but suppress it in late stages (Berg, 2000). Thus, it plays a key role in the sequestration of soil carbon. Because of the importance of carbon sequestration for the climate, the interactive effects of soil $\mathrm{N}$ content and temperature on the temperature sensitivity of $\mathrm{CO} 2$ production from $\mathrm{OM}$ decomposition is a very important issue.

\section{Effect of soil temperature on soil organic carbon decomposition.}

It is observed that there is a positive relationship between soil organic carbon decomposition and temperature sensitivity ( $\left.\mathrm{Q}_{10}\right)$ through wheat growing season when the soil fertilizered by urea or ureaform (Fig. 3). The highest values of SOCD \% were 8.4 and 8.2 at $2.4 \mathrm{Q}_{10}$ value with urea and at $2.7 \mathrm{Q}_{10}$ value with ureaform, respectively. The lowest values of SOCD \% were 2.3 and 4.4 at $2.2 \mathrm{Q}_{10}$ value with urea or ureaform, respectively. It is obviously that the SOCD rate was higher under ureaform treatment than that under urea treatment.

Giardina and Ryan, (2000), found that the decomposition of stable compounds (low quality carbon) is not temperature sensitive. Fang et al. (2005) and Conen et al. (2006) stated that both labile and stable organic compounds respond similarly to temperature increases and some of the more recent studies have found that the temperature sensitivity increases with decreased quality of the organic matter (OM). The highly significant decrease in the negative effect of nitrogen on saprotrophic $\mathrm{CO}_{2}$ production with decreasing temperature might also importantly help to explain much of the controversy in the scientific literature on the effects of nitrogen on $\mathrm{OM}$ decomposition. This positive correlation is contrary to expectations based on the carbon quality theory, which only accounts for carbon quality and predicts that the temperature sensitivity of saprotrophic decomposition of OM should increase as the activation energy of the relevant enzymatic processes rises (Davidson \& Janssens, 2006; Janssens et al., 2010 and Wetterstedt et al., 2010).

\section{4- Soil organic carbon (SOC), nitrogen content and $C: \mathbf{N}$ ratio}

Data presented in Fig. (1) Show the influence of nitrogen fertilizer (type and level) on soil $\mathrm{C}: \mathrm{N}$ ratio. In general, soil $\mathrm{C}: \mathrm{N}$ ratio values under all treatments were higher than that of initial state except that under 30\% less from the recommended level of urea (Fig.4). The recommended level showed almost the same soil C: N ratio at urea or ureaform treatment (Fig.4). The soil C: $\mathrm{N}$ ratio was higher at $15 \%$ less from the recommended urea level than that when soil treated by ureaform. The opposite trend is true at $30 \%$ less from the recommended level.

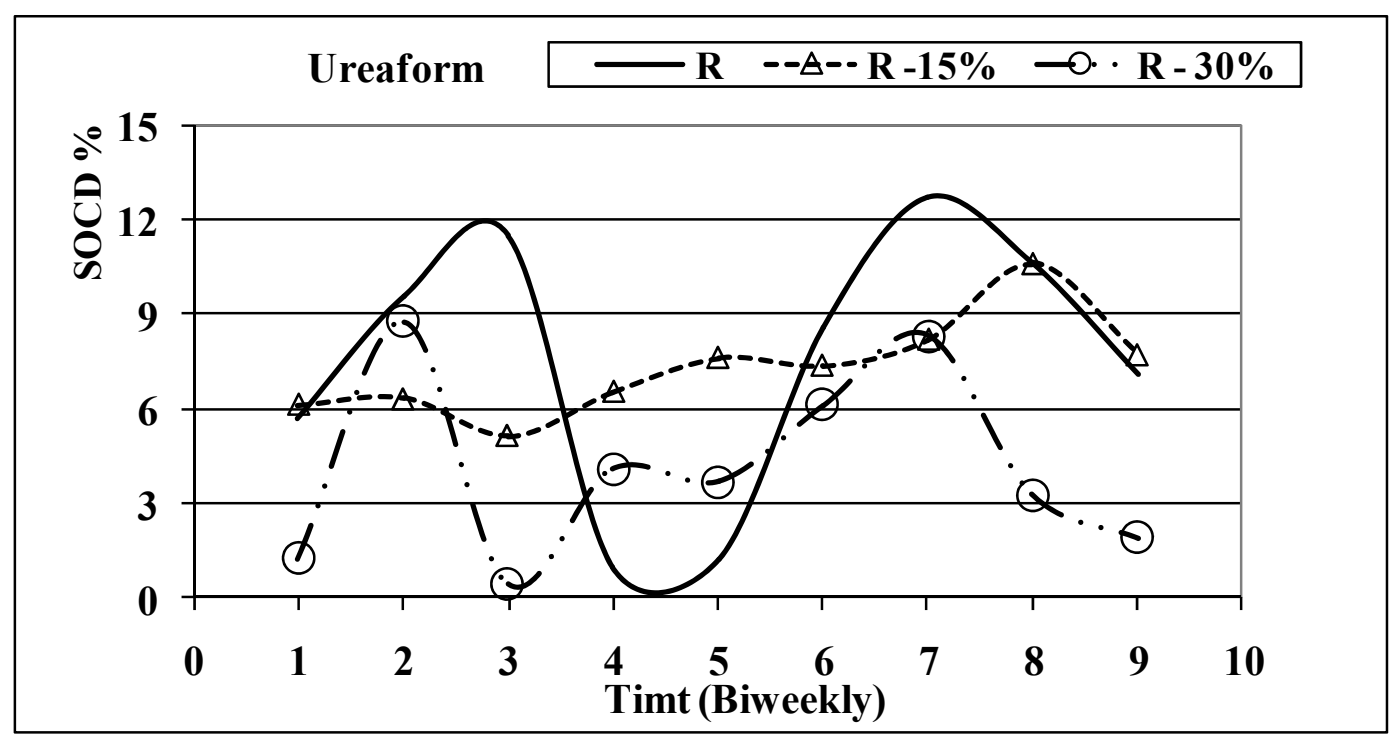

Fig. 2. Soil organic carbon decomposition (SOCD) \% in relation to time when soil was fertilized by ureaform at different levels 


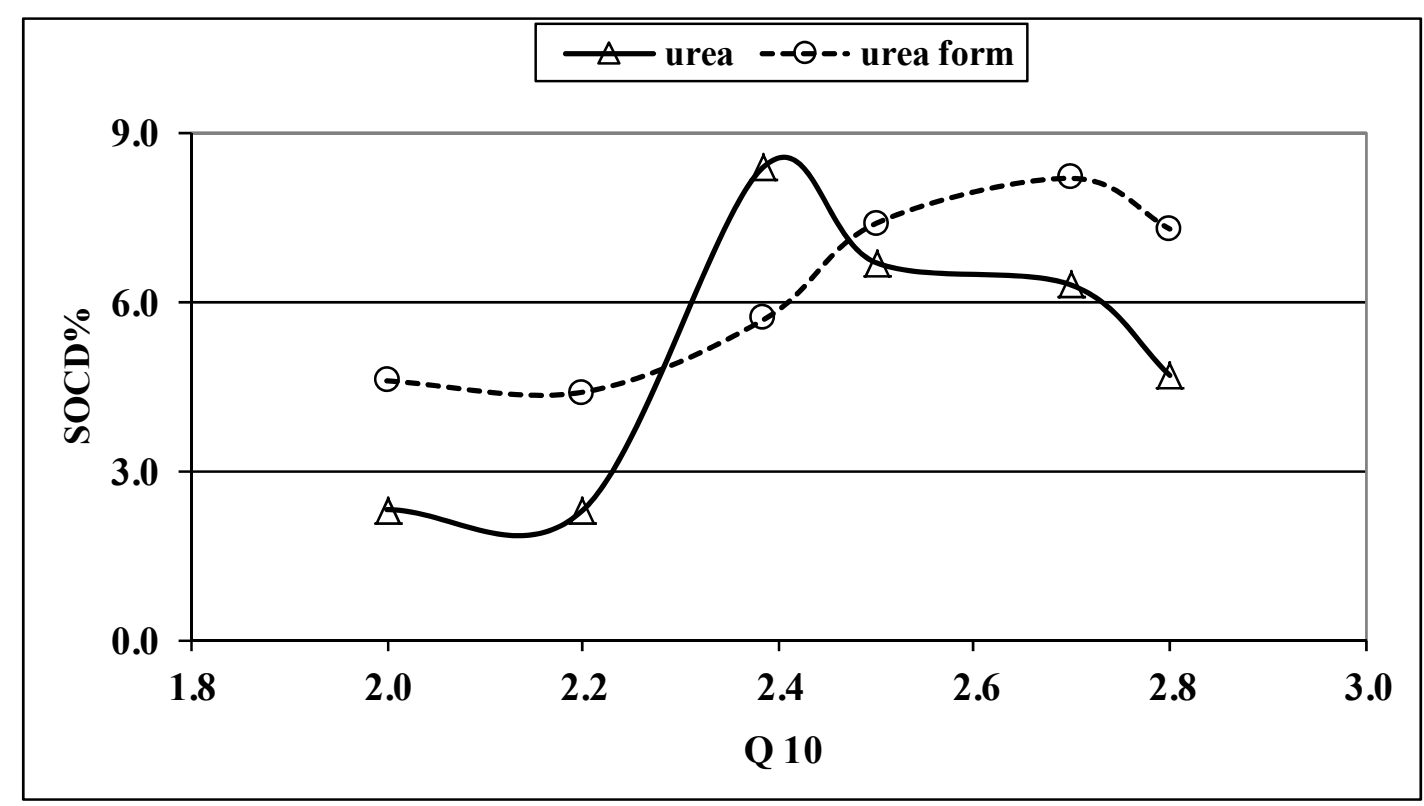

Fig. 3. Soil organic carbon decomposition (SOCD) $\%$ in relation to $\mathrm{Q}_{10}$ when soil fertilized by urea and ureaform through wheat growing season

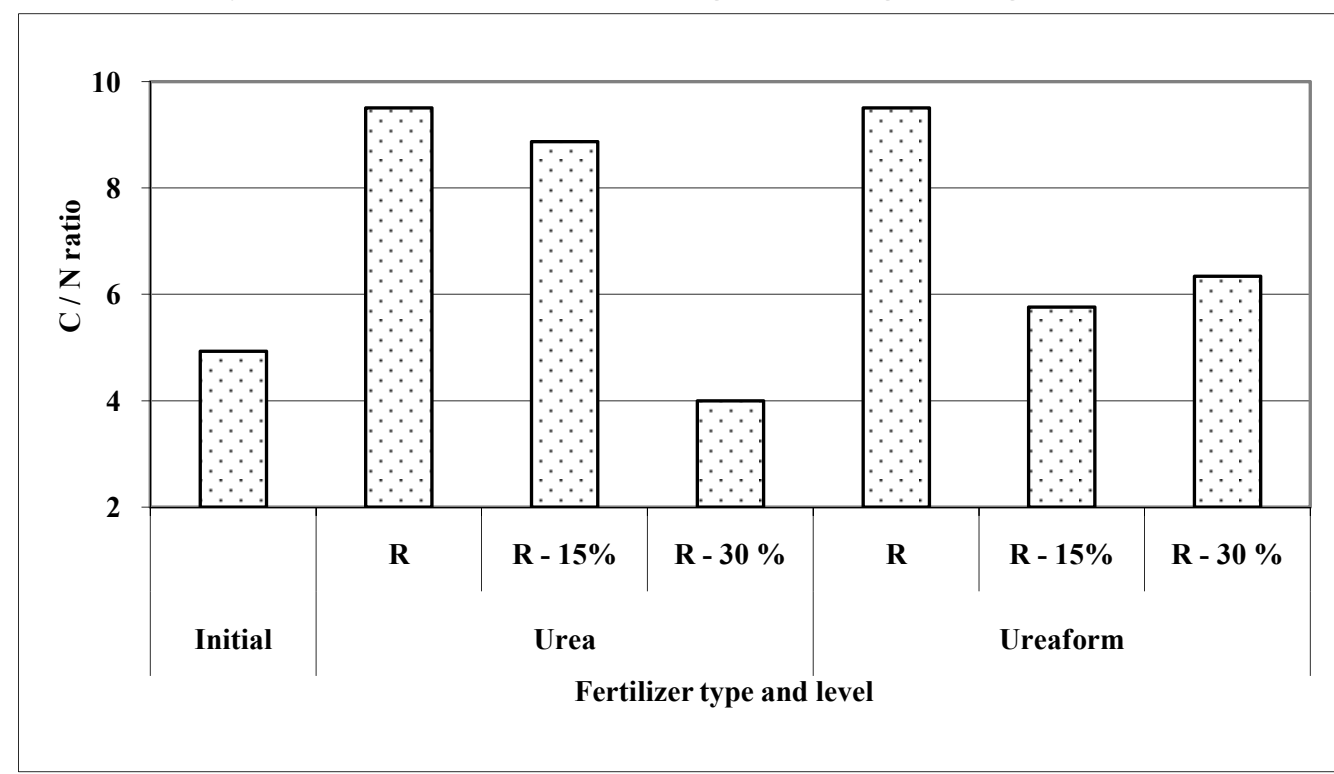

Fig.4. Soil C: $\mathbf{N}$ ratio in relation to urea and ureaform fertilizer through wheat growing season

Soils present low organic carbon content due to the high mineralization of the organic matter and the absence of harvest residues after periods of drought. On the contrary, soils with tree coverage show an increase in carbon and nitrogen (Albretch and Kandji, 2003). Additionally, residue retention can increase the proportion of SOC with a lower decomposition degree and higher $\mathrm{C}$ : $\mathrm{N}$ ratio. Thus, even a relatively small increase or decrease in soil carbon content due to changes in management practices may result in a significant net exchange of $\mathrm{C}$ between the soil $\mathrm{C}$ pool and the atmosphere.

Higher clay content is often associated with more decomposed organic matter with a lower $\mathrm{C}: \mathrm{N}$ ratio and crop residues could favour a higher soil $\mathrm{C}$ : $\mathrm{N}$ ratio. Also, C: $\mathrm{N}$ ratios might vary between $8: 1$ and $15: 1$, with an average of 12:1 (Houghton, 2003; Puget \& Lal, 2005; Yamashita et al., 2006; Brady \& Weil, 2008 and $\mathrm{Xu}$ et al., 2011). 
It may be concluded that nitrogen fertilization increases soil organic carbon decomposition but at different rates especially at high level. Ureaform as a slow release nitrogen fertilizer might slow down organic carbon decomposition which could consider a positive effect. There is other factors might be responsible or control soil organic decomposition such as temperature and $\mathrm{C}: \mathrm{N}$ ratio. If the applied organic material contains more nitrogen in proportion to the carbon, then nitrogen is released into the soil from the decomposing organic material.

\section{REFERENCES}

Albretch, A. and Kandji, S. 2003. Carbon sequestration in tropical agroforestry systems. Agric. Ecosyst. Environ, 99, 15-27,

Ajwa, H.A. and Tabatabai, M. A. 1994. Decomposition of different organic materials in soils. Biol. Fert. Soils 18: 175-182.

Abedel-Sattar, M., M. EL-Tanany and H.M.EL-Kouny 2011. Reducing Mineral Fertilizers by Using Organic Manure to Improve Washington Navel Orange Productivity and Sandy Soil Characteristics. Alexandria Sci. Exchange J., vol.32,372-380

Berg, B. \& Matzner, E.1997. Effect of N deposition on decomposition of plant litter and soil organic matter in forest systems. Environ. Reviews 5(1), 1-25.

Bowden, R.D., et al., 2004. Chronic nitrogen additions reduce total soil respiration and microbial respiration in temperate forest soils at the Harvard Forest. Forest Ecology Manag. $196,43 \mathrm{e} 56$.

Brady, C. and Weil R. R. 2008. The nature and properties of soils, 14 Edn., Pearson Prentice hall. Upper Saddle River, New Jersey Columbus, Ohia, USA,

Conen, F., Leifeld, J., Seth, B. and Alewell, C. 2006. Warming mineralises young and old soil carbon equally. Biogeosciences 3(4), 515-519.

Craine, J.M., Morrow, C., Fierer, N., 2007. Microbial nitrogen limitation increases decomposition. Ecology 88, $2105 \mathrm{e} 2113$.

Davidson, E. A. and I. A. Janssens 2006. Temperature sensitivity of soil carbon decomposition and feedbacks to climate change. Nature, 440: 165-173.

Davidson, A.; K. Savage; L. V. Verchot and R. Navarro, 2002. Minimizing artifacts and biases in chamber-based measurements of soil respiration, Agr. Forest Meteor., 113(1-4), 21-37, 2002.

Dijkstra, F. A., S. E. Hobbie, J. M. H. Knops, and P. B. Reich. 2004. Nitrogen deposition and plant species interact to influence soil carbon stabilization. Ecology Letters $7: 1192-1198$.
Elsokkary, I.H., A. E. Abd El-All, and H. E. Gomaa 2011. Microbial Biomass and Respiration of Soil Cultivated with Wheat Grown on Calcareous Soil as Influenced by Nitrogen Fertilization, Biofertilization and Farmyard Manure Application. Alexandria Sci. Exchange J., vol.32,467-478

Fang, C., Smith, P., Moncrieff, B.J. \& Smith, U.J. 2005. Similar response of labile and resistant soil organic matter pools to changes in temperature. Nature 433, 57-59.

Galloway, J.N., Dentener, F.J., Capone, D.G., Boyer, E.W., Howarth, R.W., Seitzinger, S.P., Asner, G.P., Cleveland, C.C., Green, P.A., Holland, E.A., Karl, D.M., Michaels, A.F., Porter, J.H., Townsend, A.R. and Vörösmarty, C.J. 2004. Nitrogen cycles: past, present, and future. Biogeochemistry 70(2), 153-226.

Galloway, J.N., Townsend, A.R., Erisman, J.W., Bekunda, M., Cai, Z.C., Freney, J.R., Martinelli, L.A., Seitzinger, S.P. and Sutton, M. A. 2008. Transformation of the nitrogen cycle: Recent trends, questions, and potential solutions. Science 320(5878), 889-892.

Giardina, C.P. and Ryan, M., G. 2000. Evidence that decomposition rates of organic carbon in mineral soil do not vary with temperature. Nature 404(6780), 858-861.

Hobbie, S. E. 2005. Contrasting effects of substrate and fertilizer nitrogen on the early stages of litter decomposition. Ecosystems 8(6), 644-656.

Houghton, R.A (2003). Why are estimates of the terrestrial carbon balance so different? Global Change Biol. 9, 500509.

Janssens, I. A., Dieleman, W., Luyssaert, S., Subke, J.A., Reichstein, M., Ceulemans, R., Ciais, P., Dolman, A. J., Grace, J., Matteucci, G., Papale, D., Piao, S. L., Schulze, E. D., Tang, J. and Law, B. E. 2010. Reduction of forest soil respiration in response to nitrogen deposition. Nature Geoscience 3(5), 315-322.

Janssens, I.A., Dieleman, W., Luyssaert, S., Subke, J.A., Reichstein, M., Ceulemans, R., Ciais, P., Dolman, A.J., Grace, J., Matteucci, G., Papale, D., Piao, S.L., Schulze, E.D., Tang, J. and Law, B. E. 2010. Reduction of forest soil respiration in response to nitrogen deposition. Nature Geoscience 3(5), 315-322.

Johnson, J. M. F., N. W. Barbour, and S. L. Weyer. 2005. Chemical composition of crop biomass impacts its decomposition. Soil Sci. Soc. of Am. J. 71:155-162.

Kaboneka, S., J.C. Nivyiza and L. Sibomana, 2004. Effects of Nitrogen and Phosphorus Fertilizer Addition on Wheat Straw Carbon. Decomposition in a Burundi Acidic Soil. P. 151-162. [žiūrèta 200803 03]. Prieiga per internetą http://www. ciat.cgiar.org/tsbf _institute/managing_nutrient_cycles/AfNetCh10.pdf

Khan, S. A., R. L. Mulvaney, T. R. Ellsworth, and C. W. Boast. 2007. The myth of nitrogen fertilization for soil carbon sequestration. J. of Environ. Qual. 36: 1821-1832.

Kirschbaum, M. U. F. 2000. Will changes in soil organic carbon act as a positive or negative feedback on global warming? Biogeochemistry 48(1), 21-51. 
Knorr, M., Frey, S.D. \& Curtis, P.S. 2005. Nitrogen additions and litter decomposition: A meta-analysis. Ecology 86(12), 3252-3257.

Liu, E. K., C. R. Yan, X. R. Mei, W. Q. He, S. H. Bing, L. P. Ding, Q. Liu, S. A. Liu, and T. L. Fan, 2010. Long-term effect of chemical fertilizer, straw, and manure on soil chemical and biological properties in northwest China. Geoderma, 158, 173-180.

Liu, L. L. and Greaver, T.L. 2010. A global perspective on belowground carbon dynamics under nitrogen enrichment. Ecology Letters 13(7), 819-828.

Luo, Y. and X. Zhou 2006. Soil respiration and the environment, Elsevier, Inc. All rights reserved.

Marion, G.M., and Black, C.H. 1987. The effect of time and temperature on nitrogen mineralization in Arctic Tundra soils. Soil Sci. Soc. Am. J. 1501-1508.

Parton, W., W. L. Silver, I. C. Burke, L. Grassens, M. E. Harmon, W. S. Currie, J. Y. King, E. C. Adair, L. A. Brandt, S. C. Hart, and B. Fasth. 2007. Global-scale similarities in nitrogen release patterns during long-term decomposition. Sci. 315:361-364.

Puget, P. and Lal, R. 2005. Soil organic carbon and nitrogen in a Mollisol in central Ohio as affected by tillage and land use, Soil Till. Res., 80, 201-213.

Russell, A. E., D. A. Laird, and A. P. Mallarino. 2006. Impact of nitrogen fertilization and cropping system on soil quality in Midwestern Mollisols. Soil Sci. Soc. of Am. J. 70:249-255.

Sinsabaugh, R. L., M. M. Carreiro, and D. A. Repert. 2002. Allocation of extracellular enzymatic activity in relation to litter composition, $\mathrm{N}$ deposition, and mass loss. Biogeochemistry 60:1-24.
Soil Survy Staff 1996. "Keys to Soil Taxonomy." $7^{\text {th }}$ ed. USDA. Soil Conservatio Service, U. S. Gov. print. Office, Washington, DC. 644 pp.

Stevenson, F.J. (1986) Cycles of Soil. Carbon, Nitrogen, Phosphorus, Sulfur, Micronutrients. John Wiley \& Sons, New York, NY.

Stotzky, G. (1965) Microbial respiration. p. 1550-1569. In Black, C.A. et al. (ed.), Methods of Soil Analysis. Part 2. Agron. 9. ASA, Madison, WI.

Swift, M., J., Heal, O., W. and Anderson, J., M. 1979. Decomposition in terrestrial ecosystem. Blackwell scientific publications: Berkeley, California, USA

Tarnocai, C., Canadell, J. G., Schuur, E. A. G., Kuhry, P., Mazhitova, G. and Zimov, S. 2009. Soil organic carbon pools in the northern circumpolar permafrost region. Global Biogeochemical Cycles 23.

Wetterstedt, J. A. M., Persson, T. and Agren, G. I. 2010. Temperature sensitivity and substrate quality in soil organic matter decomposition: results of an incubation study with three substrates. Global Change Biology 16(6), 1806-1819.

Xu, M., Lou, Y., Sun, X., Wang, W., Baniyamuddin, M., and Zhao, K. 2011. Soil organic carbon active fractions as early indicators for total carbon change under straw incorporation, Biol. Fert. Soils, 47, 745-752.

$\mathrm{Xu}, \mathrm{M}$. and Y. Qi 2001. Soil-surface CO2 efflux and its spatial and temporal variations in a young ponderosa pine plantation in northern California. Glob. Change Biol. 7: 667-677.

Yamashita, T., Feiner, H., Bettina, J., Helfrich, M., and Ludwig, B. 2006. Organic matter in density fractions of water-stable aggregates in silty soils: effect of land use, Soil Biol. Biochem., 38, 3222- 3234. 


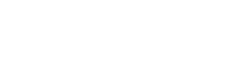

\section{تأثير النسميد النيتروجيني علي تشطل الكرون العضوي في التربة}

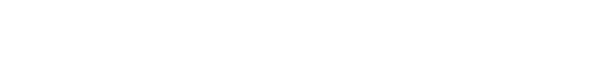

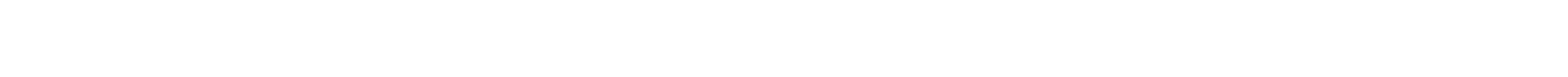

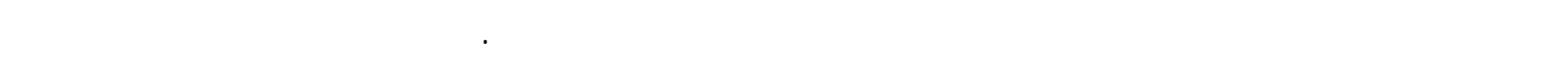
الكربون العضوي في التربة يمكن ترتيبيها تصاعديا كالاتي:

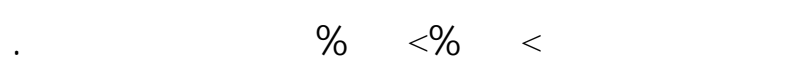

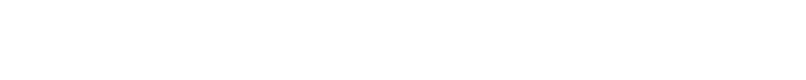

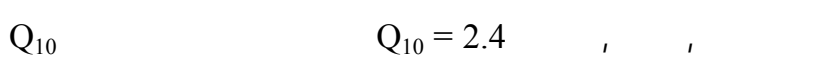

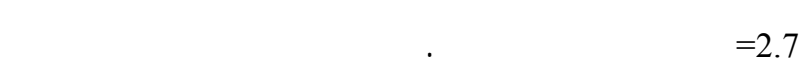

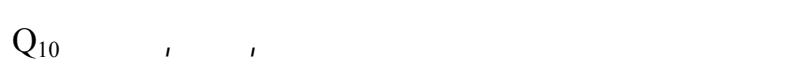

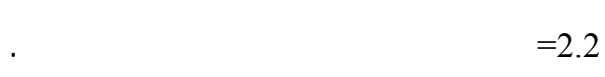

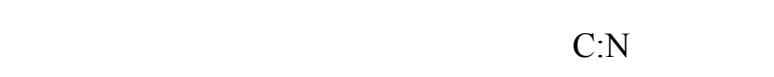

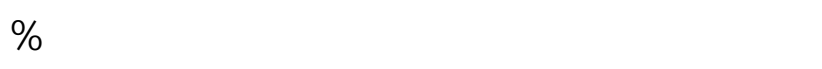

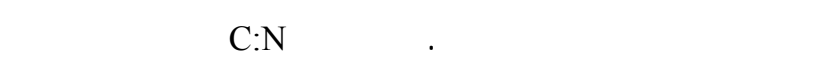

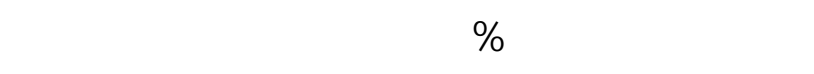

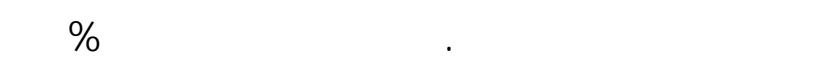
من الكمية الموصي بها.

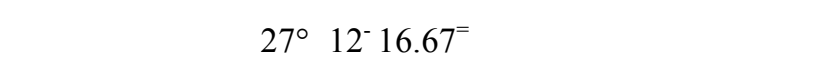

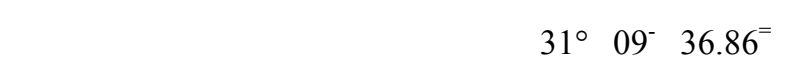

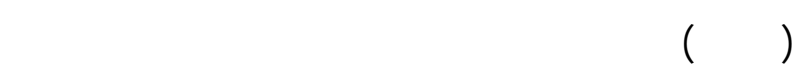

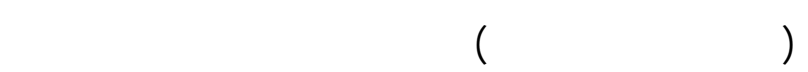
الكربون العضوي في التربة.

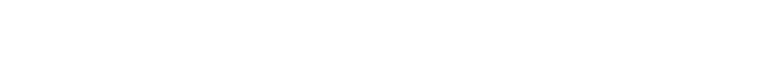

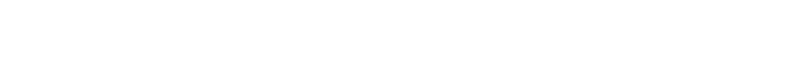
في الأسبوع اللسايع مع سماد اليوريا عند الضافة الكمية

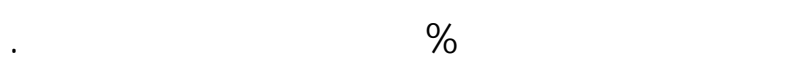

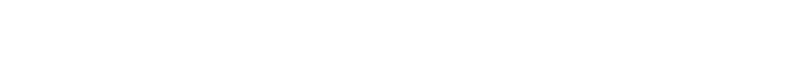

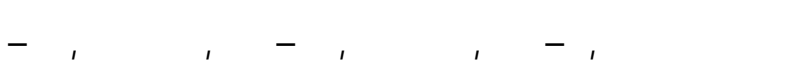

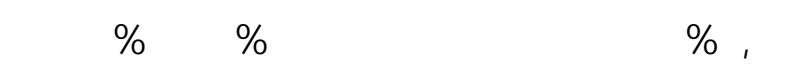

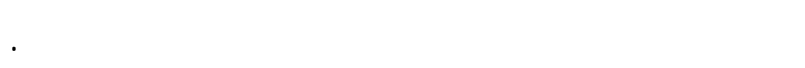

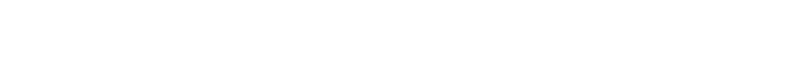

